\title{
Chronic Metabolic Acidosis Decreases Albumin Synthesis and Induces Negative Nitrogen Balance in Humans
}

\author{
Peter E. Ballmer, ${ }^{*}$ Margaret A. McNurlan, ${ }^{\$ \neq}$ Henry N. Hulter, "Susan E. Anderson, ${ }^{\mathbf{5}}$ Peter J. Garlick, ${ }^{\star}$ and Reto Krapf ${ }^{\star 1}$ \\ ${ }^{*}$ Department of Medicine, University of Berne, Inselspital, CH-3010 Berne, Switzerland; ${ }^{8}$ The Rowett Research Institute, Aberdeen, \\ AB2 9SB, United Kingdom; ${ }^{\ddagger}$ Department of Surgery, State University of New York at Stony Brook, New York, 11794-8191; "Division of \\ Nephrology, Department of Medicine, San Francisco General Hospital, University of California, San Francisco, California 94110; and \\ 'Department of Medicine, Kantonsspital, CH-9007 St. Gallen, Switzerland
}

\begin{abstract}
Chronic metabolic acidosis has been previously shown to stimulate protein degradation. To evaluate the effects of chronic metabolic acidosis on nitrogen balance and protein synthesis we measured albumin synthesis rates and urinary nitrogen excretion in eight male subjects on a constant metabolic diet before and during two different degrees of chronic metabolic acidosis $\left(\mathrm{NH}_{4} \mathrm{Cl} 2.1 \mathrm{mmol} / \mathrm{kg}\right.$ body weight, low dose group, and $4.2 \mathrm{mmol} / \mathrm{kg}$ body weight, high dose group, orally for $7 \mathrm{~d}$ ). Albumin synthesis rates were measured by intravenous injection of $\left[{ }^{2} \mathrm{H}_{5}\right.$ ring $]$ phenylalanine $(43 \mathrm{mg} / \mathrm{kg}$ body weight, 7.5 atom percent and 15 atom percent, respectively) after an overnight fast. In the low dose group, fractional synthesis rates of albumin decreased from $9.9 \pm 1.0 \%$ per day in the control period to $8.4 \pm 0.7$ (n.s.) in the acidosis period, and from $8.3 \pm 1.3 \%$ per day to $6.3 \pm 1.1(P<0.001)$ in the high dose group. Urinary nitrogen excretion increased significantly in the acidosis period $(\Sigma \Delta 634 \mathrm{mmol}$ in the low dose group, 2,554 mmol in the high dose group). Plasma concentrations of insulin-like growth factor-I, free thyroxine and tri-iodothyronine were significantly lower during acidosis. In conclusion, chronic metabolic acidosis causes negative nitrogen balance and decreases albumin synthesis in humans. The effect on albumin synthesis may be mediated, at least in part, by a suppression of insulin-like growth factorI, free thyroxine and tri-iodothyronine. (J. Clin. Invest. 1995. 95:39-45.) Key words: albumin - metabolic acidosis protein synthesis $\cdot$ nitrogen balance $\cdot$ insulin-like growth factor-I
\end{abstract}

\section{Introduction}

Chronic metabolic acidosis is associated with severe growth retardation in humans and rats (1-4), and an increase in muscle protein degradation in rats (5-7). A putative causal role of metabolic acidosis in the development of whole body protein catabolism is supported by the fact that alkali-induced correction of metabolic acidosis normalized growth in children with

Address correspondence to Peter E. Ballmer, M.D., Department of Medicine, University of Berne, Inselspital, CH-3010 Berne, Switzerland. Phone: 31-632-21-11; FAX: 31-632-96-46.

Received for publication 30 June 1994 and in revised form 2 September 1994.

J. Clin. Invest.

(C) The American Society for Clinical Investigation, Inc.

0021-9738/95/01/0039/07 \$2.00

Volume 95, January 1995, 39-45 renal tubular acidosis (4) and improved nitrogen balance significantly in acidotic patients with moderate to severe chronic renal insufficiency (8).

In dogs, $\mathrm{HCl}$-induced acute metabolic acidosis increased leucine oxidation and plasma concentrations of essential and non-essential amino acids, whereas alkalosis, induced by $\mathrm{NaHCO}_{3}$ infusion, had the opposite effect (9). Chronic mineral acidosis accelerated both whole body protein degradation and oxidation in rats (7). Moreover, chronic metabolic acidosis in rats has also been suggested to result in negative nitrogen balance based on isolated 24 or $48 \mathrm{~h}$ urinary nitrogen excretion values $(10,11)$.

In humans, the influence of sustained metabolic acidosis per se on protein or nitrogen metabolism has not been reported. However, prolonged fasting associated with ketoacidosis was shown to induce protein wasting resulting in increased nitrogen excretion in obese subjects (12). Moreover, wasting of lean body mass is a common feature in patients with chronic uremic acidosis (13). The increase in whole body protein degradation reported in acute (14) and chronic (15) mineral acidosis in normal subjects might be an important pathogenic factor responsible for the loss of lean body mass in human uremia. In addition, the subjects with chronic mineral acidosis were also reported to exhibit a simultaneous increase in whole body protein synthesis and leucine oxidation in the post-absorptive state (15). However, the effects of pure sustained metabolic acidosis, in the absence of other metabolic abnormalities, on $24 \mathrm{~h}$ nitrogen balance have not previously been reported in humans.

Skeletal muscle protein degradation has been reported to play a quantitatively important role in whole body protein catabolism in metabolic acidosis and can be normalized by systemic alkali administration in rats with uremic acidosis $(6,11)$. In cultured myocytes in vitro, where protein degradation was enhanced in acidified media, protein synthesis decreased by nearly $30 \%$ when $\mathrm{pH}$ was lowered from 7.4 to 7.2 , and increased to nearly $130 \%$ at $\mathrm{pH} 7.6(16)$. In addition, acute respiratory acidosis has been reported to decrease muscle protein synthesis in rats (17), whereas increasing extracellular $\mathrm{pH}$ over the range 7.4 to 8.9 stimulated protein synthesis by nearly $60 \%$ in the working TRIS or Hepes-buffered perfused rat heart (18). Even the effect of severe chronic renal insufficiency (acidosis presumed) on muscle protein synthesis remains controversial as both decreased $(5,19)$ and normal rates have been reported (20).

The effects of metabolic acidosis on nonmuscle proteins, such as albumin, may contribute substantially to nitrogen imbalance in chronic metabolic acidosis. The synthesis of albumin, the most abundant hepatic secretory protein, is decreased in various clinically important conditions, e.g., septicemia or trauma (21). Metabolic acidosis accompanies many of these 
conditions, but its contribution to the decrease in protein/albumin synthesis has not been reported in any species.

Therefore, the aims of the present study were to investigate the independent effects of chronic extrarenal $\left(\mathrm{NH}_{4} \mathrm{Cl}\right.$-induced $)$ metabolic acidosis on nitrogen metabolism and albumin synthesis in normal human subjects.

\section{Methods}

Albumin synthesis rates and urinary nitrogen excretion were measured in eight healthy male subjects in a dedicated metabolic room with controlled regular intake of meals, that were part of another metabolic study (22), before and during $\mathrm{NH}_{4} \mathrm{Cl}$-induced metabolic acidosis. All subjects ingested a constant metabolic diet for at least $5 \mathrm{~d}$ before the base-line measurements and throughout the experiment. The diet contained 2,800

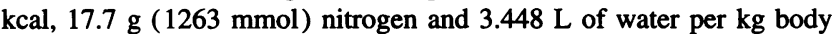
weight per day. Diet nitrogen was verified by direct analysis. Nitrogen intake by direct assay was found to be higher than the value of $14.2 \mathrm{~g}$ estimated previously from nutrition tables (22).

Experimental design. After the baseline measurements of albumin synthesis and urinary nitrogen excretion at the end of the control period, two different levels of metabolic acidosis were induced by oral $\mathrm{NH}_{4} \mathrm{Cl}$ administration. Four subjects $(30 \pm 6.4 \mathrm{yr}$, mean $\pm \mathrm{SD})$ were fed 2.1 mmol $\mathrm{NH}_{4} \mathrm{Cl}$ per $\mathrm{kg}$ body weight in gelatine capsules divided in six doses (low dose group), whereas the other four subjects (27.3 $\pm 7.3 \mathrm{yr}$ ) received $4.2 \mathrm{mmol} \mathrm{NH} \mathrm{NL}_{4} / \mathrm{kg}$ daily in six divided doses (high dose group). Albumin synthesis rates were again measured after $7 \mathrm{~d}$ of $\mathrm{NH}_{4} \mathrm{Cl}$ ingestion, when a new acid-base steady-state was obtained in all subjects. Nitrogen excretion rates were measured daily during acidosis.

Measurement of albumin synthesis rates. Albumin synthesis rates were measured after an overnight fast by flooding with $\left[{ }^{2} \mathrm{H}_{5}\right.$ ring $]$ phenylalanine, as described previously $(23,24)$. In brief, $43 \mathrm{mg}$ of [ ${ }^{2} \mathrm{H}_{5}$ ring] phenylalanine (Tracer Technologies, Sommerville, MA) per $\mathrm{kg}$ body weight with an isotopic enrichment of 7.5 atom percent in the first measurement, and 15 atom percent in the second measurement were intravenously injected over $10 \mathrm{~min}$. The $\left[{ }^{2} \mathrm{H}_{5}\right.$ ring $]$ phenylalanine was mixed with unlabeled L-phenylalanine (Merck, Darmstadt, Germany) in $0.45 \% \mathrm{NaCl}$ and the solution sterile filtered by the hospital pharmacy. Blood samples were drawn from the opposite cubital vein at 10 -min intervals up to $90 \mathrm{~min}$. Plasma samples were stored at $-20^{\circ} \mathrm{C}$. After thawing, albumin was isolated by ethanol extraction from trichloroacetic acid precipitated plasma proteins as described previously $(23,25,26)$. In every subject the purity of the albumin isolates was checked by SDSgel electrophoresis indicating a single band corresponding to human albumin. After repeat washes with $0.2 \mathrm{~mol} /$ liter perchloric acid, the albumin was hydrolyzed in $6 \mathrm{~mol} / \mathrm{liter} \mathrm{HCl}$ for $24 \mathrm{~h}$ at $105-110^{\circ} \mathrm{C}$. The hydrolysates were purified by washing with distilled water and then dried down in a stream of $\mathrm{N}_{2}$. Phenylalanine was converted to $\beta$ phenethylamine by enzymatic conversion with tyrosine decarboxylase (Sigma, Poole, Dorset, UK) and the enrichment of the heptafluorobutyryl derivative of $\beta$-phenethylamine was measured on a VG 12-250 quadrupole mass spectrometer under electron impact ionisation (VG Masslab, Manchester, UK) as described previously $(24,27)$. The plasma free phenylalanine enrichment, reflecting the precursor pool for albumin synthesis, was determined by gas chromatography mass spectrometry on the VG 12-250 mass spectrometer, using the tertiary butyldimethylsilyl derivative and electron impact ionisation (28).

Calculation of albumin synthesis rates. Albumin synthesis was calculated as a fractional synthesis rate (FSR) ${ }^{1}$ (percent/day), i.e., the percentage of the intravascular albumin mass synthesized per day (23).

The FSR was calculated by dividing the increase in $\left[{ }^{2} \mathrm{H}_{5}\right.$ ring]-

1. Abbreviations used in this paper: FSR, fractional synthesis rate; HDG, high-dose group; LDG, low-dose group; $\mathrm{f}_{4}$, free plasma thyroxin; $\mathrm{T}_{3}$, tri-iodthyronine; TSH, thyroid-stimulating hormone.
Table I. Characteristics of Subjects

\begin{tabular}{llllll}
\hline & \multicolumn{2}{c}{ Control } & & \multicolumn{2}{c}{ Acidosis } \\
\cline { 2 - 3 } \cline { 5 - 6 } \cline { 5 - 6 } & Weight & $\begin{array}{c}\text { Plasma } \\
\text { albumin }\end{array}$ & & Weight & $\begin{array}{c}\text { Plasma } \\
\text { albumin }\end{array}$ \\
\hline Low dose group & & & & \\
$\quad 1$ & 65.1 & 43 & 64.1 & 41 \\
2 & 53.8 & 45 & & 53.4 & 47 \\
3 & 61.2 & 43 & 60.5 & 42 \\
4 & 62.0 & 46 & 60.9 & 43 \\
Mean \pm SD & $60.5 \pm 4.8$ & $44.3 \pm 1.5$ & $59.7 \pm 4.5^{\ddagger}$ & $43.3 \pm 2.6$ \\
High dose group & & & & \\
5 & 66.4 & 42 & 65.2 & 42 \\
6 & 76.2 & 43 & & 73.7 & 42 \\
7 & 56.5 & 47 & & 53.5 & 45 \\
8 & 58.3 & 47 & 57.4 & 46 \\
Mean \pm SD & $64.4 \pm 9.0$ & $44.8 \pm 2.6$ & $62.5 \pm 8.9 *$ & $43.8 \pm 2.1$ \\
Total & $62.4 \pm 7.0$ & $44.5 \pm 2.0$ & $61.1 \pm 6.7$ & $43.5 \pm 2.2$ \\
& & & &
\end{tabular}

Body weight (in $\mathrm{kg}$ ) and plasma albumin concentrations (in g/liter) of the subjects in the control period and during metabolic acidosis. ${ }^{*} P$ $=0.033 ;{ }^{\ddagger} P=0.015$ versus control period.

phenylalanine enrichment in albumin by the area under the curve of the precursor enrichment, from the equation $(23,29,30)$ :

FSR $=\left(P_{2}-P_{1}\right) \times 100 / A$

where $P_{2}$ is the isotopic enrichment of phenylalanine in albumin at 90 $\mathrm{min}$, and $P_{1}$ at $50 \mathrm{~min}$. The area under the curve for the precursor enrichment was calculated by summation of the areas between successive measurement points on the curve of the plasma free phenylalanine enrichment. The appropriate section of the curve was determined by subtracting one secretion time, i.e., the time between start of injecting the label and the appearance of the first enriched albumin molecules, because the albumin molecules appearing at the time corresponding to $P_{1}$ were synthesized one secretion time earlier.

Urinary nitrogen excretion. In all subjects $24-\mathrm{h}$ urine was collected for $4 \mathrm{~d}$ in the control period and for $7 \mathrm{~d}$ during $\mathrm{NH}_{4} \mathrm{Cl}$ administration. 24-h nitrogen excretion was determined photometrically after wet incineration followed by formation of indophenol with salicylate and hypochlorite in triplicate (31). The reported changes in urinary nitrogen excretion are corrected for the change in nitrogen intake (as $\mathrm{NH}_{4} \mathrm{Cl}$ ) by subtraction.

Other measurements. Plasma albumin concentrations were determined with bromcresol purple. Plasma acid-base composition was determined in arterialized venous blood samples as described previously $(22$, 32,33 ).

Plasma concentrations of insulin-like growth factor-I (IGF-I), free thyroxin $\left(\mathrm{f} \mathrm{T}_{4}\right)$, tri-iodothyronine $\left(\mathrm{T}_{3}\right)$ and of thyroid-stimulating hormone (TSH) were measured by standard radio-immuno-assay methods.

Statistics. The results are given as means \pm SD. Statistical comparisons were performed using the paired Student's $t$ test (two-tailed) with a significance level of $P<0.05$.

The study protocol was approved by the ethics committee of the University of Berne School of Medicine.

\section{Results}

All subjects tolerated the study well. In Table I body weights and plasma albumin concentrations are summarized. All subjects in both groups lost weight in response to $\mathrm{NH}_{4} \mathrm{Cl}$ administration. Plasma albumin concentration decreased significantly 


\begin{tabular}{|c|c|c|c|c|c|c|}
\hline & \multicolumn{3}{|c|}{ Control } & \multicolumn{3}{|c|}{ Acidosis } \\
\hline & $\mathrm{pH}$ & $\mathrm{pCO}_{2}$ & $\mathrm{HCO}_{3}^{-}$ & $\mathrm{pH}$ & $\mathrm{pCO}_{2}$ & $\mathrm{HCO}_{3}^{-}$ \\
\hline \multicolumn{7}{|c|}{ Low dose group } \\
\hline 1 & 7.425 & 37.6 & 24.3 & 7.357 & 29.9 & 16.2 \\
\hline 2 & 7.439 & 35.6 & 24.0 & 7.361 & 34.1 & 19.5 \\
\hline 3 & 7.416 & 35.0 & 23.6 & 7.329 & 32.5 & 19.7 \\
\hline 4 & 7.445 & 37.7 & 25.9 & 7.390 & 35.0 & 21.1 \\
\hline Mean \pm SD & $7.431 \pm 0.013$ & $36.5 \pm 1.4$ & $24.5 \pm 1.0$ & $7.375 \pm 0.019 *$ & $32.9 \pm 2.2$ & $19.1 \pm 2.1^{*}$ \\
\hline \multicolumn{7}{|c|}{ High dose group } \\
\hline 5 & 7.430 & 40.3 & 26.7 & 7.349 & 30.0 & 16.5 \\
\hline 6 & 7.419 & 38.3 & 24.7 & 7.268 & 30.2 & 13.8 \\
\hline 7 & 7.444 & 35.7 & 24.4 & 7.246 & 31.2 & 13.5 \\
\hline 8 & 7.451 & 37.9 & 26.4 & 7.347 & 30.0 & 16.4 \\
\hline Mean $\pm S D$ & $7.436 \pm 0.014$ & $38.1 \pm 1.9$ & $25.6 \pm 1.2$ & $7.303 \pm 0.053 *$ & $30.4 \pm 0.6^{*}$ & $15.1 \pm 1.6^{\ddagger}$ \\
\hline Total & $7.434 \pm 0.013$ & $37.3 \pm 1.8$ & $25.0 \pm 1.2$ & $7.339 \pm 0.054 *$ & $31.6 \pm 2.0^{*}$ & $17.1 \pm 2.8^{\ddagger}$ \\
\hline
\end{tabular}

Blood acid-base composition of the subject in the control period and during metabolic acidosis ( $\mathrm{pH}$ in $\mathrm{U} ; \mathrm{pCO}_{2}$ in $\mathrm{mmHg} ; \mathrm{HCO}_{3}^{-}$in $\mathrm{mmol} /$ liter). ${ }^{*} P<0.05 ;{ }^{\ddagger} P<0.001$ versus control period.

in the high dose group, whereas a nonsignificant fall occurred in the low dose group.

In Table II, the plasma acid base composition of all subjects on the study days (i.e., when albumin synthesis rates were measured) are summarized. $\mathrm{NH}_{4} \mathrm{Cl}$ administration induced a significant decrease in plasma $\mathrm{HCO}_{3}^{-}$concentrations in both the low (mean $\Delta=5.4 \mathrm{mmol} / \mathrm{liter}, P<0.05$ ) and the high dose group (mean $\Delta=10.5 \mathrm{mmol} / \mathrm{liter}, P<0.001$ ).

Fig. 1 demonstrates the enrichment in plasma free phenylalanine, reflecting the precursor pool for albumin synthesis. Shortly after the intravenous injection of the large dose of

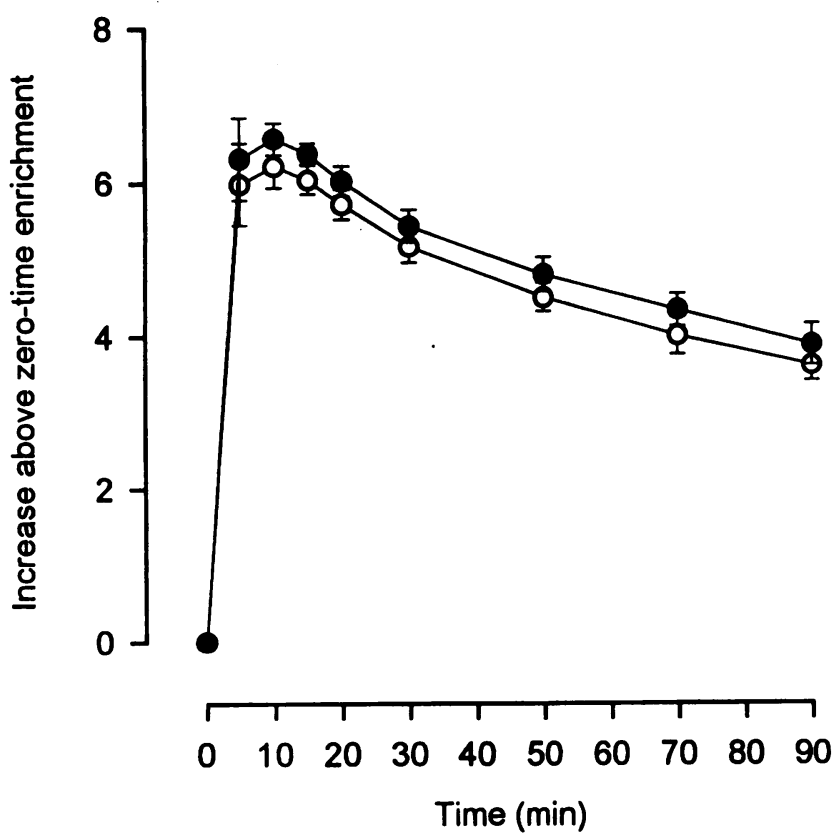

Figure 1. Plasma free phenylalanine enrichment after injecting $43 \mathrm{mg}$ $\left[{ }^{2} \mathrm{H}_{5}\right.$ ring ] phenylalanine per $\mathrm{kg}$ body weight at zero time. Open symbols in the control and filled symbols in the acidosis period. $\left[{ }^{2} \mathrm{H}_{5}\right.$ ring $]$ phenylalanine the enrichment in plasma free phenylalanine reached a peak value, succeeded by a plateau for approximately $20 \mathrm{~min}$. Thereafter, a progressive slow decline in plasma free phenylalanine enrichment occurred up to $90 \mathrm{~min}$. Metabolic acidosis had no influence on plasma free phenylalanine enrichments.

In Fig. 2, the curves for the phenylalanine enrichment in albumin of both measurements are shown. With a delay of $\sim 30$ min (i.e., the secretion time; 23 ) after injecting the large dose of phenylalanine the enrichment in albumin started to increase and followed an approximately linear time-course thereafter ( see 23). In 3 out of 4 subjects in the low dose $\mathrm{NH}_{4} \mathrm{Cl}$ group the enrichments were slightly lower in the acidotic period, whereas one subject showed a clear decrease in enrichment while he was acidotic. In contrast, in the high dose group all four subjects had substantially lower enrichments in albumin under acidotic conditions. As an indication of the accuracy of the mass spectrometry analyses all curves were smooth and the rise in enrichment of albumin occurred at the same time, i.e., at about $30 \mathrm{~min}$. This was also reflected by the secretion times, which were not different between the two measurements. In the first measurement the secretion time was $32.5 \pm 1.6 \mathrm{~min}$ versus $32.3 \pm 2.1 \min (P=0.7 ; n=8)$ in the second measurement. In Table III the FSRs are summarized separately for the low and the high dose group. Control values were well within the expected range of albumin synthesis $(23,25,26,34,35)$. All subjects showed a decrease of FSR. However, this difference reached statistical significance only in the high dose group and when the two groups were combined.

Urinary nitrogen excretion in the low dose group averaged $997 \pm 116 \mathrm{mmol} / 24 \mathrm{~h}$ (i.e., $14.0 \pm 1.6 \mathrm{~g} / 24 \mathrm{~h}$ ) in the control period and $1088 \pm 116 \mathrm{mmol} / 24 \mathrm{~h}$ (i.e., $15.2 \pm 1.6 \mathrm{~g} / 24 \mathrm{~h} ; P$ $=0.156$ ) during acidosis (after correction for $\mathrm{NH}_{4} \mathrm{Cl}$ ingestion), while in the high dose group nitrogen excretion averaged $1012 \pm 180 \mathrm{mmol} / 24 \mathrm{~h}$ (i.e., $14.2 \pm 2.5 \mathrm{~g} / 24 \mathrm{~h}$ ) and $1377 \pm 236$ mmol/24 h (i.e., $19.3 \pm 3.3 \mathrm{~g} / 24 \mathrm{~h} ; P<0.001$ ), respectively. Ingestion of high dose $\mathrm{NH}_{4} \mathrm{Cl}$ induced an increased nitrogen excretion rate $(1377 \pm 236 \mathrm{mmol} / 24 \mathrm{~h})$ in comparison with the 


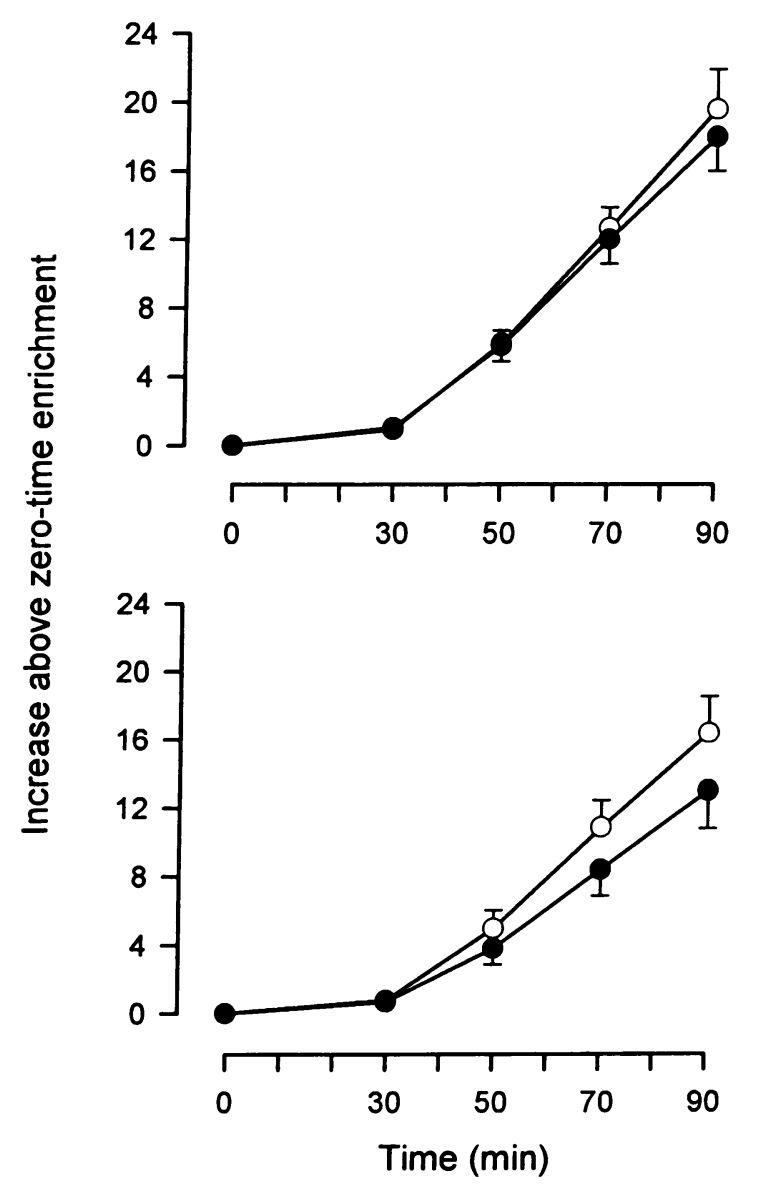

Figure 2. Phenylalanine enrichment of plasma albumin after injecting $43 \mathrm{mg}\left[{ }^{2} \mathrm{H}_{5}\right.$ ring] phenylalanine per $\mathrm{kg}$ body weight at zero time. Open symbols in the control and filled symbols in the acidosis period; (upper panel) low dose $\mathrm{NH}_{4} \mathrm{Cl}$ group; (lower panel) high dose $\mathrm{NH}_{4} \mathrm{Cl}$ group.

low dose group $(1088 \pm 116 \mathrm{mmol} / 24 \mathrm{~h}, P<0.001)$. Fig. 3 depicts the daily changes in urinary nitrogen excretion during acidosis compared with control and the sum of the daily changes during acidosis. The daily nitrogen excretion is expressed as the difference from the average daily excretion during the control period. As the dietary intake was identical throughout, this method of presentation is equivalent to a nitrogen balance, if stool losses are assumed to be constant. The cumulative increase in nitrogen excretion averaged $634 \mathrm{mmol}$ on day 7 of low dose $\mathrm{NH}_{4} \mathrm{Cl}$ and $2554 \mathrm{mmol}$ in the high dose $\mathrm{NH}_{4} \mathrm{Cl}$ group (Fig. 3). The plasma concentrations of IGF-I, $\mathrm{fT}_{4}, \mathrm{~T}_{3}$, and TSH are shown in Table IV. IGF-I, $\mathrm{fT}_{4}$, and $\mathrm{T}_{3}$ all showed small, but statistically significant declines during the acidosis period, when the low and high dose groups were combined, with no change in TSH. There were no significant correlations by linear regression analysis between the plasma hormone concentrations and the other measured metabolic variables.

\section{Discussion}

The present data demonstrate for the first time in any species that chronic metabolic acidosis decreases albumin synthesis, and induces a state of sustained negative nitrogen balance. Thus, the present study provides strong evidence that chronic meta-
Table III. Albumin Synthesis Rates

\begin{tabular}{ccl}
\hline & \multicolumn{2}{c}{ FSR } \\
\cline { 2 - 3 } & Control & Acidosis \\
\hline Low dose group & & \\
1 & 10.1 & 9.3 \\
2 & 8.7 & 7.9 \\
3 & 11.0 & 7.9 \\
4 & 9.8 & 8.5 \\
Mean \pm SD & $9.9 \pm 1.0$ & $8.4 \pm 0.7$ \\
High dose group & & \\
5 & 9.4 & 7.5 \\
6 & 7.0 & 5.8 \\
7 & 9.4 & 6.9 \\
8 & 7.4 & 5.1 \\
Mean \pm SD & $8.3 \pm 1.3$ & $6.3 \pm 1.1^{*}$ \\
Total & $9.1 \pm 1.4$ & $7.4 \pm 1.4^{\ddagger}$ \\
\end{tabular}

Albumin synthesis of the subjects in the control period and during metabolic acidosis, expressed as FSR in percent per day (\%/d). ${ }^{*} P$ $<0.01 ;{ }^{\ddagger} P<0.001$ versus control period.

bolic acidosis not only increases whole body protein degradation and amino acid oxidation (15), but has profound effects on protein synthesis.

Different degrees of metabolic acidosis were induced with two different levels of $\mathrm{NH}_{4} \mathrm{Cl}$ as reflected by the significant difference in steady-state plasma concentrations of bicarbonate between the low and the high dose group (Table II). Ingestion of $2.1 \mathrm{mmol} \mathrm{NH}_{4} \mathrm{Cl}$ per $\mathrm{kg}$ body weight (low dose group) induced a non-significant increase of nitrogen excretion, whereas $4.2 \mathrm{mmol}$ (high dose group) induced a significant and sustained increase in urinary nitrogen excretion, suggestive of a graded effect of metabolic acidosis. Therefore, metabolic acidosis may be an important mediator of negative nitrogen balance, increased protein breakdown, and decreased protein synthesis in acidotic patients with chronic renal failure, sepsis or trauma.

The cumulative increases in urinary nitrogen excretion over the 7-d acidosis period are equivalent to a daily loss of $\sim 8$ grams of protein in the low dose group and of $\sim 31$ grams in the high dose group. Thus, mild to moderate chronic metabolic acidosis induces a quantitatively impressive protein degradation in a dose- or severity-dependent way. Albumin synthesis rate decreased significantly in the subjects with the more severe metabolic acidosis, whereas in the low dose group a smaller, but nonsignificant decline in FSR of albumin occurred. However, as with nitrogen excretion the data on albumin synthesis are also suggestive of a graded response. The observed decrease in albumin synthesis (15) is not inconsistent with the reported increase in whole body protein synthesis, which is an aggregate change in all the protein of the body, each of which is regulated separately. Albumin synthesis accounts for $\sim 10 \%$ of liver protein synthesis (36), i.e., $\sim 10-15 \mathrm{~g}$ protein per day in a healthy subject (23). In conditions with severe protein/albumin losses, such as the nephrotic syndrome, synthesis rates of albumin can be augmented approximately by a factor of 1.5 (25), thus contributing substantially to the net whole body protein synthesis rate of $\sim 200 \mathrm{~g}$ protein per day in an adult (37). Assuming an 


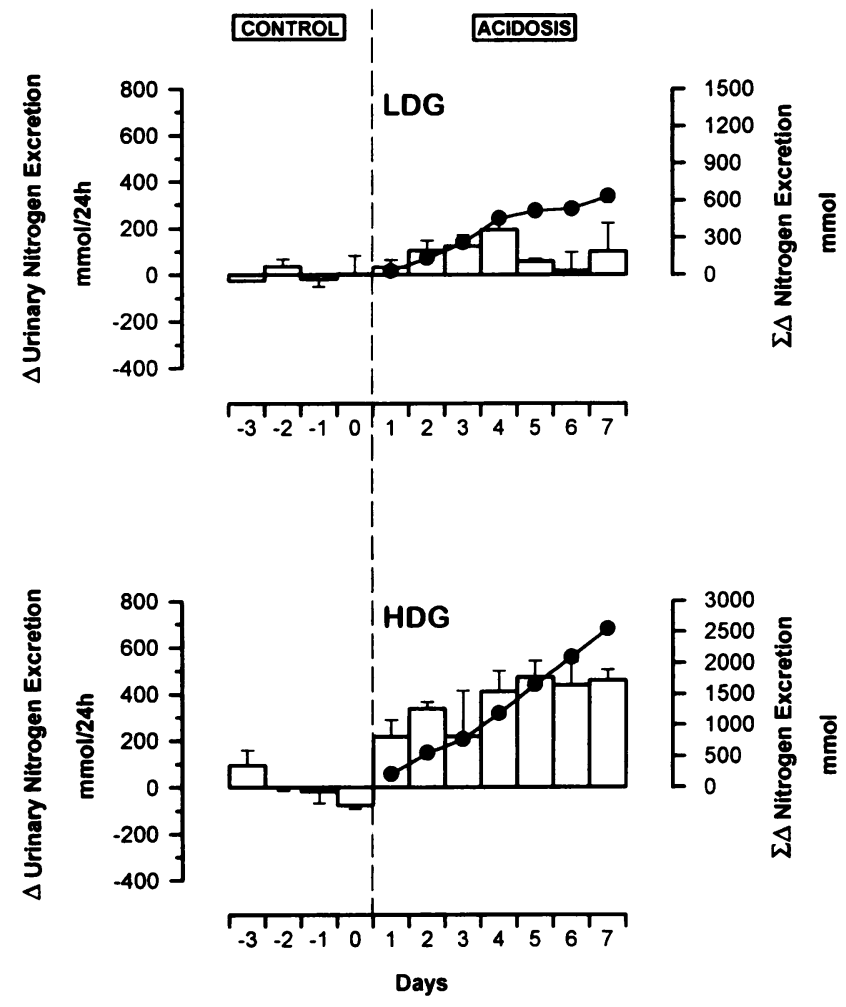

Figure 3. Effects of metabolic acidosis on urinary nitrogen (N) excretion. $L D G$, low dose $\mathrm{NH}_{4} \mathrm{Cl}$ group; $H D G$, high dose $\mathrm{NH}_{4} \mathrm{Cl}$ group. $\Delta$ urinary $\mathbf{N}$ excretion denotes the daily changes in urinary $\mathrm{N}$ excretion, as compared with the average urinary $\mathrm{N}$ excretion in the control period. $\Sigma \Delta \mathrm{N}$ excretion denotes the cumulative changes in urinary $\mathrm{N}$ excretion from the average $\mathrm{N}$ excretion in the control period.

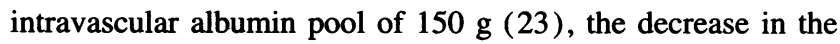
albumin FSR by $\sim 25 \%$ in the high dose group relates to a decrease of protein synthesis of $\sim 3 \mathrm{~g} / 24 \mathrm{~h}$. The difference in the corrected urinary nitrogen excretion of $5 \mathrm{~g} / 24 \mathrm{~h}$ between the control and the acidosis period equals $\sim 31 \mathrm{~g}$ of protein. Thus, assuming no change in albumin catabolism, the observed decrement of $3 \mathrm{~g} / 24 \mathrm{~h}$ albumin synthesis rate accounts for $10 \%$ of the protein equivalent of the corrected urinary nitrogen losses. In many catabolic conditions suppression of albumin synthesis might be more severe, since other factors, such as low energy/ protein intake and inflammatory stimuli (e.g., cytokines) are known to inhibit albumin synthesis $(21,36)$. Nutrient intake was controlled in the present study by a constant metabolic diet, which provided an identical amount of energy and protein in the control and acidosis periods. An effect of nutrition on albumin synthesis rates is therefore excluded. However, the remaining
$90 \%$ protein equivalent to the urinary nitrogen losses probably occurred mainly through changes in total body protein breakdown (15).

A potential error in measuring albumin synthesis in the acidosis period may have occurred through an increased catabolism of proteins within the liver associated with changes in the endogenous supply of unlabeled amino acids. Whereas the equilibration of the hepatic precursor pool enrichment for albumin synthesis with the plasma free amino acid enrichment, which was used as the precursor for calculating the albumin synthesis rate, was previously demonstrated after a flooding dose of labeled amino acid in normal healthy subjects (23), no data are available in acidotic subjects. However, as compared to other methods, i.e., the constant infusion technique (30), the large amount of labeled amino acid injected in the present study is more likely to achieve an isotopic equilibration between the hepatic precursor pool and the plasma phenylalanine, which would minimize any error in albumin synthesis rates.

The possibility might be considered that the observed increment in urinary nitrogen excretion during chronic $\mathrm{NH}_{4} \mathrm{Cl}$ loading is associated with an offsetting reduction in stool nitrogen excretion, thereby preventing negative balance. This possibility is unlikely for at least two reasons. First, stool nitrogen excretion has been reported as unchanged during a 3- $\mathrm{d} \mathrm{NH}_{4} \mathrm{Cl}$ load (3.1-4.2 mmol/ $\mathrm{kg}$ per $24 \mathrm{~h}$ ) in normal human subjects ingesting a constant whole food diet (38). Second, the increment in urinary nitrogen excretion (corrected for changes in nitrogen intake) during the steady-state of acidosis in the present studies (high dose group) averaged 365 mmol or $5.11 \mathrm{~g} / 24 \mathrm{~h}$. This increment exceeds the measured values for total stool nitrogen excretion $(0.9-1.4 \mathrm{~g} / 24 \mathrm{~h})$ as assessed during a wide variety of whole-food dietary intakes (38-40). Thus, due to the magnitude of the observed changes, a reduction in stool nitrogen output is extremely unlikely to account for the increased urinary nitrogen excretion.

We have also investigated potential hormonal mechanisms mediating the acidosis-induced negative nitrogen balance and down-regulation of albumin synthesis. Growth hormone, IGFI, thyroid hormones and cortisol are among the most important hormones regulating protein synthesis/degradation. Growth hormone administration was shown to stimulate amino acid transport and protein synthesis (41), an effect which is probably mediated by IGF-I (42). Thyroid hormones enhance hepatic albumin mRNA expression, and hypothyroidism has opposite effects (36), while cortisol is known to directly increase albumin synthesis and degradation in humans (43). In rats, chronic metabolic acidosis has been demonstrated to stimulate muscle proteolysis in the presence of an increase in urinary corticosterone excretion, but to have no effect on protein synthesis (11).

In the present study, we report for the first time a decrease in IGF-I plasma concentration in response to chronic metabolic

Table IV. Hormone Plasma Concentrations

\begin{tabular}{|c|c|c|c|c|c|c|c|c|}
\hline & \multicolumn{4}{|c|}{ Control } & \multicolumn{4}{|c|}{ Acidosis } \\
\hline & IGF-I & $\mathrm{fT}_{4}$ & $T_{3}$ & TSH & IGF-I & $\mathrm{fT}_{4}$ & $\mathrm{~T}_{3}$ & TSH \\
\hline Mean $\pm S D$ & $42.5 \pm 15.4$ & $17.6 \pm 1.6$ & $2.3 \pm 0.5$ & $2.2 \pm 1.0$ & $31.6 \pm 14.7 *$ & $15.9 \pm 1.7^{*}$ & $2.0 \pm 0.5^{*}$ & $2.1 \pm 1.1$ \\
\hline
\end{tabular}

Plasma concentrations of insulin-like growth factor-I (IGF-I in nmol/liter), free thyroxine ( $\mathrm{fT}_{4}$ in pmol/liter), tri-jodthyronine $\left(\mathrm{T}_{3}\right.$ in nmol/liter), and thyroid-stimulating hormone (TSH in mU/liter) in the control period and during metabolic acidosis. $* P<0.05$ versus control period. 
acidosis in normal human subjects. This finding is consistent with recent preliminary data in children with renal tubular acidosis, where both growth hormone and IGF-I levels were decreased (44). Our findings are also consistent with the reported observation that metabolic acidosis depressed the plasma concentration and hepatic gene expression of IGF-I in rats (45). Although IGF-I has not been directly shown to stimulate albumin synthesis, its action is generally anabolic, stimulating protein synthesis in the whole body (42). Thus, it is tempting to speculate that the observed suppression of albumin synthesis may not be directly mediated by metabolic acidosis per se, but may be mediated via the fall in IGF-I. This mechanism may have important implications for protein metabolism in chronic renal failure, since the kidney itself is a site of IGF-I production (46). Whether the binding of IGF-I to IGF-binding proteins is altered in patients with chronic renal failure has not been reported. However, the potential depression of IGF-I in chronic renal failure (47) might be mediated by both metabolic acidosis and a renal mass-mediated decrease of renal IGF-I production.

The fall in $\mathrm{fT}_{4}$ and $\mathrm{T}_{3}$ plasma concentrations resulting from chronic metabolic acidosis has also not been reported previously in humans, and indicates that metabolic acidosis has inhibitory actions on the peripheral thyroid hormones. In newborn lambs, it was recently reported that $\mathrm{HCl}$-induced acidosis lowered plasma concentrations of thyroid hormones (48). Since thyroid hormones are known to have anabolic effects (36), the decrease of $\mathrm{fT}_{4} / \mathrm{T}_{3}$ may be another pathogenic factor which contributes to the decreased synthesis rates of albumin or other proteins in the present study. However, while it is possible that the changes in plasma levels of both IGF-I and the thyroid hormones are linked to the decrease in albumin synthesis, a causative role for these hormones has not been proved by the present study.

In contrast to observations in rats (11), cortisol excess has no known pathogenic role in altered protein synthesis and negative nitrogen balance in humans with acidosis. We and others have shown that chronic metabolic acidosis does not affect cortisol homeostasis in humans $(33,49)$.

Two clinically important consequences arise from our observations. First, the magnitude of both increased nitrogen excretion, resulting from an increase in whole body protein degradation (15), and decreased albumin synthesis, indicates that metabolic acidosis may be among the most important factors in protein wasting seen in disease states such as chronic renal failure, sepsis, and trauma. Second, our data suggest that correction of metabolic acidosis in such patients may be important to prevent protein (e.g., muscle protein) wasting. Correction of acidosis may be particularly important in patients with acute or chronic renal failure because it could be predicited to reduce the accumulation of urea, ameliorate uremic symptoms, and therefore, to reduce the need for dialytic treatment.

In conclusion, chronic extrarenal metabolic acidosis induces a dose-dependent and substantial decrease of albumin synthesis in normal human subjects, which may contribute in part to the sustained negative nitrogen balance. The decline in the plasma concentrations of IGF-I and thyroid hormones suggests that metabolic acidosis may act, at least in part, by suppressing regulatory hormones of albumin synthesis and protein anabolism, although the causative role of the changes in plasma hormone levels has to be demonstrated in the future.

\section{Acknowledgments}

We are grateful for mass spectrometry measurements by Mr. A. G. Calder, and for superb technical assistance by Mrs. S. Schütz-Hofmann and Ms. M. Turgay.
This work was supported by a grant from the Swiss National Foundation (Nr. 32-31290.91 to P. E. Ballmer), by institutional funding, Department of Medicine, Kantonsspital St. Gallen (to R. Krapf), by Nestec Ltd., Vevey, Switzerland (M. A. McNurlan), and by Grampian Research into Intestinal Disorders (P. J. Garlick). The Rowett Research Institute is supported by the Scottish Office of the Agriculture and Fisheries Department.

\section{References}

1. Butler, A. M., J. L. Wilson, and S. Farber. 1936. Dehydration and acidosis with calcification of renal tubules. J. Pediatr. 8:489-499.

2. Albright, F., W. V. Consolazio, F. S. Coombs, H. W. Sulkowith, and J. H. Talbott. 1940. Metabolic studies and therapy in a case of nephrolithiasis with rickets and dwarfism. Bull. Johns Hopkins Hosp. 66:7-33.

3. Nash, M. A., A. D. Torrado, I. Greifer, A. Spitzer, and C. H. Edelmann Jr. 1972. Renal tubular acidosis in infants and children. J. Pediatr. 80:738-748.

4. McSherry, E., and R. Curtis Morris 1978. Attainment and maintenance of normal stature with alkali therapy in infants and children with classic renal tubular acidosis. J. Clin. Invest. 61:509-527.

5. Garber, A. J. 1978. Skeletal muscle protein and amino acid metabolism in experimental chronic uremia in the rat. J. Clin. Invest. 62:623-632.

6. May, R. C., R. A. Kelly, and W. E. Mitch. 1987. Mechanisms for defects in muscle protein metabolism in rats with chronic uremia: the influence of metabolic acidosis. J. Clin. Invest. 79:1099-1103.

7. May, R. C., T. Masud, B. Logue, J. Bailey, and B. England. 1992. Chronic metabolic acidosis accelerates whole body proteolysis and oxidation in awake rats. Kidney Int. 41:1535-1542.

8. Papadoyannakis, N. J., C. J. Stefanidis, and M. McGeown. 1984. The effect of the correction of metabolic acidosis on nitrogen and potassium balance of patients with chronic renal failure. Am. J. Clin. Nutr. 40:623-627.

9. Rodriguez, N. R., J. M. Miles, W. Schwenk, and M. W. Haymond. 1989. Effects of acute metabolic acidosis and alkalosis on leucine metabolism in conscious dogs. Diabetes. 38:847-853.

10. Williams, B., E. Layward, and J. Walls. 1991. Skeletal muscle degradation and nitrogen wasting in rats with chronic metabolic acidosis. Clin. Sci. (Lond.). 80:457-462.

11. May, R. C., R. A. Kelly, and W. E. Mitch. 1986. Metabolic acidosis stimulates protein degradation in rat muscle by a glucocorticoid-dependent mechanism. J. Clin. Invest. 77:614-621.

12. Hannaford, M. C., L. A. Leiter, R. G. Josse, M. B. Goldstein, E. B. Marliss, and M. L. Halperin. 1982. Protein wasting due to acidosis of prolonged fasting. Am. J. Physiol. 243:E251-E256.

13. Mitch, W. E., R. C. May, and B. J. Maroni. 1989. Mechanisms for abnormal protein metabolism in uremia. J. Am. Coll. Nutr. 8:305-309.

14. Straumann, E., U. Keller, D. Küry, D. Bloesch, A. Thélin, M. J. Arnaud and W. Stauffacher. 1992. Effect of acute acidosis and alkalosis on leucine kinetics in man. Clin. Physiol. (Oxf.). 12:39-51.

15. Reaich, D., S. M. Channon, C. M. Scrimgeour, and T. H. J. Goodship 1992. Ammonium chloride-induced acidosis increases protein breakdown and amino acid oxidation in humans. Am. J. Physiol. 263:E735-E739.

16. England, B. K., J. L. Chastain, and W. E. Mitch. 1991. Abnormalities in protein synthesis and degradation induced by extracellular $\mathrm{pH}$ in $\mathrm{BC} 3 \mathrm{H} 1$ myocytes. Am. J. Physiol. 260:C277-C282.

17. Preedy, V. R., and P. J. Garlick. 1988. The influence of restraint and infusion on rates of muscle protein synthesis in the rat. Biochem. J. 251:577580.

18. Fuller, S. J., C. J. Gaitanaki, and P. H. Sudgen. 1989. Effects of increasing extracellular $\mathrm{pH}$ on protein synthesis and protein degradation in the perfused working rat heart. Biochem. J. 259:173-179.

19. Garibotto, G., R. Russo, M. R. Sala, P. Ancarani, C. Robaudo, A. Sofia, G. Deferrari, and A. Tizianello. 1992. Muscle protein turnover and amino acid metabolism in patients with chronic renal failure. Miner. Electrolyte Metab. 18:217-221.

20. Li, J. B., and S. J. Wassner. 1986. Protein synthesis and degradation in skeletal muscle of chronically uremic rats. Kidney Int. 29:1136-1143.

21. Moshage, H. J., B. E. M. Kleter, J. F. van Pelt, H. M. J. Roelofs, G. M. Kleuskens, and S. H. Yap. 1988. Fibrinogen and albumin synthesis are regulated at the transcriptional level during the acute phase response. Biochim. Biophys. Acta 950:450-454.

22. Krapf, R., R. Vetsch, W. Vetsch, and H. N. Hulter. 1992. Chronic metabolic acidosis increases the serum concentration of 1,25-dihydroxyvitamin $D$ in humans by stimulating its production rate. J. Clin. Invest. 90:2456-2463.

23. Ballmer, P. E., M. A. McNurlan, E. Milne, S. D. Heys, V. Buchan, A. G. Calder, and P. J. Garlick. 1990. Measurement of albumin synthesis in man: a new approach employing stable isotopes. Am. J. Physiol. 259:E797-E803.

24. McNurlan, M. A., P. Essen, A. Thorell, A. G. Calder, S. E. Anderson, O. Ljungqvist, A. Sandgren, I. Grant, I. Tjäder, P. E. Ballmer, J. Wernerman, and 
P. J. Garlick. 1994. Response of protein synthesis in human skeletal muscle to insulin: an investigation with L- $\left[{ }^{2} \mathrm{H}_{5}\right]$ phenylalanine. Am. J. Physiol. 267:E102E108.

25. Ballmer, P. E., B. K. Weber, P. Roy-Chaudhury, M. A. McNurlan, H Watson, D. A. Power, and P. J. Garlick. 1992. Elevation of albumin synthesis rates in nephrotic patients measured with $\left[1{ }^{13} \mathrm{C}\right]$ leucine. Kidney Int. 41:132138.

26. Ballmer, P. E., D. Walshe, M. A. McNurlan, H. Watson, P. W. Brunt and P. J. Garlick. 1993. Albumin synthesis rates in liver cirrhosis: correlation with the Child-Turcotte score. Hepatology. 18:292-297.

27. Calder, A. G., S. E. Anderson, I. Grant, M. A. McNurlan, and P. J. Garlick. 1992. The determination of low $d_{5}$-phenylalanine enrichment $(0.002-0.09$ atom percent excess) after conversion to phenylethylamine, in relation to protein turnover studies by gas chromatography/electron ionization mass spectrometry. Rapid Commun. Mass Spectrom. 6:421-424.

28. Calder, A. G., and A. Smith. 1988. Stable isotope ratio analysis of leucine and ketoisocaproic acid in blood plasma by gas chromatography/mass spectrometry. Use of tertiary butyldimethylsilyl derivates. Rapid Commun. Mass Spectrom. 2:14-16.

29. Yudkoff, M., I. Nissim, W. McNellis, and R. Polin. 1987. Albumin synthesis in premature infants: determination of turnover with $\left[{ }^{15} \mathrm{~N}\right]$ glycine. Pediatr. Res. 21:49-53.

30. De Feo, P., F. F. Horber, and M. W. Haymond. 1992. Meal stimulation of albumin synthesis: a significant contributor to whole body protein synthesis in humans. Am. J. Physiol. 263:E794-E799.

31. Lauber, K. 1976. Photometric determination of nitrogen. Wet incineration followed by formation of indophenol blue with salicylate/hypochlorite. Clin. Chim. Acta. 67:107-110.

32. Forster, H. V., J. A. Dempsey, J. Thomson, E. Vidruk, and G. A. DoPico. 1972. Estimation of arterial $\mathrm{PU}_{2}, \mathrm{PCO}_{2}, \mathrm{pH}$, and lactate from arterialized venous blood. J. Appl. Physiol. 32:134-137.

33. Krapf, R., I. Beeler, D. Hertner, and H. N. Hulter. 1991. Chronic respiratory alkalosis: the effect of sustained hyperventilation on renal regulation of acidbase equilibrium. N. Engl. J. Med. 324:1394-1401.

34. McFarlane, A. S. 1963. Measurement of synthesis rates of liver-produced plasma proteins. Biochem. J. 89:277-290.

35. Wilkinson, P., and C. L. Mendenhall. 1963. Serum albumin turnover in normal subjects and patients with cirrhosis measured by ${ }^{131}$ I-labeled albumin. Clin. Sci. Lond. 25:281-292.
36. Rothschild, M. A., M. Oratz, and S. S. Schreiber. 1988. Serum albumin Hepatology. 8:385-401.

37. Garlick, P. J., M. A. McNurlan, and P. E. Ballmer. 1991. Influence of dietary protein intake on whole-body protein turnover in humans. Diabetes Care. 14:1189-1198.

38. Schwartz, W. B. R. L. Jenson, and A. S. Relman. 1954. Disposition of acid administered to sodium-depleted subjects: renal response and role of whole body buffers. J. Clin. Invest. 33:587-597.

39. Clark, H. E., J. M. Howe, J. L. Magee, and J. L. Malzer. 1972. Nitrogen balances of adult human subjects who consumed four levels of nitrogen from a combination of rice, milk and wheat. J. Nutr. 102:1647-1654.

40. Clark, H. E., W. H. Monn, J. L. Malzer, and R. L. Pang. 1974. Nitrogen retention of young men who consumed between 16 and 8 grams of nitrogen from a combination of rice, wheat, chicken and milk. Am. J. Clin. Nutr. 27:1059-1064.

41. Fryburg, D. A., R. A. Gelfand, and E. J. Barret. 1991. Growth hormone acutely stimulates forearm muscle protein synthesis in normal humans. Am. J. Physiol. 260:E499-E504.

42. Schwander, J., C. Hauri, J. Zapf, and E. Froesch. 1983. Synthesis and secretion of insulin-like growth factor and its binding protein by the perfused rat liver: dependence on growth hormone status. Endocrinology. 113:297-305.

43. Grossman, J., A. A. Yallow, and R. E. Weston. 1960. Albumin degradation and synthesis as influenced by hydrocortisone, corticotropin and infection. Metab olism. 39:1900-1908.

44. Caldas, A., and M. Fontoura. 1993. Effects of chronic metabolic acidosis (CMA) on 24-hour growth hormone secretion. J. Am. Soc. Nephrol. 4:828a. (Abstr.)

45. Challa, A., W. Chan, R. J. Krieg, M. A. Thabet, F. Liu, R. L. Hintz, and J. C. M. Chan. 1993. Effect of metabolic acidosis on the expression of insulinlike growth factor and growth hormone. Kidney Int. 44:1224-1227.

46. Hammerman, M. R., G. Ryan, and S. B. Miller. 1992. Expression of insulin-like growth factor in adult and embryonic kidney. Miner. Electrolyte Metab. 18:253-255.

47. Maniar, S., D. Laouari, V. Motel, M. Déchaux, and C. Kleinknecht. 1993. Growth hormone (GH) resistance induced by chronic metabolic acidosis (CMA) in uremic rats. J. Am. Soc. Nephrol. 4:829a. (Abstr.)

48. Cabello, G., and C. Wrutniak. 1989. Influence of experimental acidosis on the concentrations of thyreostimulin (TSH) and iodothyronines (total T4, free T4, T3) in the plasma of the newborn lamb. Reprod. Nutr. Dev. 29:509-515.

49. Schambelan, M., A. Sebastian, B. A. Katuna, and E. Arteaga. 1987 Adrenocortical hormone secretory response to chronic $\mathrm{NH}_{4} \mathrm{Cl}$-induced metabolic acidosis. Am. J. Physiol. 252:E454-E460. 